\title{
"Longe dos olhos, longe do coração": invisibilização e homofilia nas redes associativas.
}

\author{
Rui Zanata Jr. ${ }^{1}$ \& Marcelo Kunrath Silva ${ }^{2}$ - UFRGS (Brasil)
}

\begin{abstract}
Resumo
Investigações realizadas com duas associações de moradores de Porto Alegre evidenciaram que as distâncias estruturais e relacionais entre os indivíduos se reproduzem na conformação das redes associativas. Desse modo, o objetivo deste artigo é identificar e analisar mecanismos que permitem explicar a associação entre as distâncias estrutural e relacional - ou seja, a homofilia - observada no associativismo urbano. Frente à impossibilidade de abordar adequadamente os diversos mecanismos causais da homofilia, optou-se por focalizar um que, hipoteticamente, parece desempenhar papel central num contexto de profunda desigualdade como o brasileiro: o mecanismo de invisibilização. Assim, são investigadas as relações e os deslocamentos de indivíduos como um recurso metodológico para analisar os padrões homofílicos observados na atuação das organizações às quais eles pertencem. A análise realizada possibilita sustentar empiricamente a presença e importância do mecanismo invisibilização. De um lado, a invisibilização se expressa na tendência de que indivíduos em posições subalternizadas estejam ausentes dos espaços e relações que estruturam o cotidiano dos indivíduos pesquisados. Tal ausência diminui (e, no limite, impede) a possibilidade de que relações significativas e duradouras se estabeleçam entre desiguais. Por outro, mesmo quando aquela tendência é rompida e os entrevistados interagem com indivíduos e organizações em posições inferiorizadas, observa-se que tal interação tende a não produzir vínculos relevantes.
\end{abstract}

Palavras-chave: associativismo urbano, distância social, invisibilização, homofilia.

\begin{abstract}
Previous researches conducted on two neighborhood associations in Porto Alegre have shown that structural and relational distances between individuals are reproduced in the conformation of the associative networks. The purpose of this paper is to identify and analyze the mechanisms that explain the association between structural and relational distances - i.e. the homophily - observed in the urban associations. Faced with the impossibility of covering adequately the various causal mechanisms of homophily, we chose to address a mechanism that appears to play a central role in contexts of profound inequality as in Brazil: the mechanism of invisibility. Therefore, the paper focuses on the relationships and the urban displacements of two individuals as a methodological resource to analyze the homophylic patterns observed in organizations in which they participate. The research findings enables support empirically the presence and importance of the mechanism of invisibility. On one hand, the invisibility is expressed in the propensity of individuals in subordinated positions are absent from the spaces and relationships that structure the daily lives of individuals surveyed. This absence decreases (and, ultimately, prevent) the possibility that meaningful and lasting

\footnotetext{
${ }^{1}$ Mestrando em Sociologia (UFRGS). ruizanatajr@yahoo.com.br.

2 Professor do Departamento de Sociologia/UFRGS e do Programa de Pós-graduação em Sociologia/UFRGS. mksilva@ufrgs.br.
} 
REDES- Revista hispana para el análisis de redes sociales

Vol.22,\#4, Junio 2012

http://revista-redes.rediris.es

relationships are established between unequals. On the other hand, even when that propensity is overcome and the respondents interact with individuals and organizations in inferior positions, it is observed that such interaction tends not to produce relevant links.

Key-words: urban associations, social distance, invisibility, homophily.

\section{Introdução}

Investigações empíricas realizadas previamente com duas associações de moradores de Porto Alegre (uma localizada numa vila popular e outra situada num bairro de classe média) evidenciaram que as distâncias estruturais e relacionais entre os agentes sociais se reproduzem também na conformação das redes do associativismo urbano. Dessa maneira, identificou-se uma expressiva tendência entre as associações de moradores pesquisadas de se relacionarem com indivíduos, entidades, instituições e organizações ocupantes de posições similares no espaço social. Em linhas gerais, foi verificado que as distâncias estruturais se desdobram em distâncias relacionais, gerando laços sociais homofílicos - ou seja, relações entre indivíduos que compartilham características socioeconômicas e culturais (estilos de vida) semelhantes.

Em um primeiro estudo (Zanata Jr. 2009), observou-se uma composição e um volume muito diferenciados dos capitais sociais - ou a sua reconversão em outras formas de recursos - detidos pelas duas associações de moradores pesquisadas. Assim, a associação situada no bairro de classe média fundamentava suas ações através da mobilização de amplo leque de relações com políticos, empresários, organizações sociais e instituições. Já a associação localizada na vila popular possuía uma rede relacional muito menor e, sobretudo, constituída por atores com posições sociais bem menos proeminentes do que as ocupadas pelos agentes com os quais a primeira associação costumava se relacionar. Esses "achados" empíricos informam que as conexões sociais (responsáveis, em grande medida, pelo acesso a diversos tipos de oportunidades e recursos) destas duas associações de moradores são estabelecidas com indivíduos e organizações situados em posições relativamente similares no espaço social.

No segundo trabalho (Silva; Zanata Jr. 2010), por sua vez, a partir de uma pesquisa empírica sobre as relações sociais de uma associação localizada em bairro de classe média de Porto Alegre, reafirmou-se a constatação de uma expressiva segmentação do tecido associativo da cidade em decorrência das marcantes distâncias estruturais e relacionais entre seus habitantes. Observou-se que as associações de moradores dos bairros de classe média tendem a estabelecer 
REDES- Revista hispana para el análisis de redes sociales

Vol.22,\#4, Junio 2012

http://revista-redes.rediris.es

vínculos e realizar ações com associações de moradores em posições semelhantes no espaço social. Ao mesmo tempo, elas tendem a não manter relações com associações de bairros e vilas populares, ainda que espacialmente próximas. Dessa forma, a proximidade social, ao invés da proximidade territorial, parece ser o fator central na definição das possibilidades de relacionamento entre as associações de moradores da cidade.

Frente a esses resultados, coloca-se a finalidade central deste artigo, qual seja: identificar e analisar mecanismos causais que permitem explicar a associação entre distância social estrutural e distância social relacional observada no associativismo urbano de Porto Alegre. Em outras palavras, o objetivo principal é contribuir para uma melhor explicação sobre como a homofilia - a qual é, em geral, tomada como um dado - é produzida e reproduzida no mundo associativo. Nesse sentido, adotase o argumento hipotético de que são os mecanismos associados à (re)produção de fronteiras sociais e simbólicas que explicam, em grande medida, a presença reduzida ( $e$, no limite, a ausência) de relações sociais entre indivíduos e grupos sociais em posições desiguais, configurando, assim, um associativismo urbano caracterizado pela segmentação e pela homofilia.

Frente à impossibilidade de abordar adequadamente os diversos mecanismos que concorrem para a (re)produção de fronteiras sociais e simbólicas nos limites de um artigo, optou-se por focalizar um mecanismo específico que, hipoteticamente, parece desempenhar um papel central em um contexto de profunda desigualdade como o brasileiro: o mecanismo de invisibilização. Argumenta-se, assim, que a invisibilização de indivíduos e grupos em posições inferiorizadas por parte daqueles ocupantes de posições superiores na hierarquia social constitui um mecanismo importante na constituição das fronteiras sociais e simbólicas em espaços sociais marcados por desigualdades extremas. A hipótese aventada é de que a invisibilização tende a bloquear os contatos entre indivíduos desigualmente situados no espaço social ao estabelecer fronteiras sociais e simbólicas entre eles, contribuindo, assim, na reprodução das distâncias sociais e relacionais no mundo social e, mais especificamente, no associativismo urbano.

Para a operacionalização deste argumento, foram construídas duas dimensões teórico-analíticas com vistas a explorar como opera na realidade social o mecanismo de invisibilização. A primeira delas diz respeito à significativa tendência de que atores sociais situados em posições de classe subalternas estariam ausentes das redes de relações dos (e, assim, dos espaços de sociabilidade frequentados pelos) agentes sociais em posições dominantes no espaço social. Já a segunda 
REDES- Revista hispana para el análisis de redes sociales

Vol.22,\#4, Junio 2012

http://revista-redes.rediris.es

dimensão estaria vinculada a padrões socialmente segmentados de estruturação dos deslocamentos urbanos (de onde vem e para onde vão) realizados pelos indivíduos em seu cotidiano.

Essas duas dimensões constitutivas do mecanismo de invisibilização produziriam, hipoteticamente, situações, encontros e eventos sociais conformados por indivíduos socialmente similares, com o consequente ocultamento dos "diferentes-desiguais". Tal dinâmica social explicaria, em certa medida, como e por que a homofilia se (re)produz no espaço social e, de forma mais específica, no associativismo urbano.

Conforme expressam os parágrafos acima, este artigo focaliza as relações e percursos de indivíduos como um recurso metodológico para a análise dos padrões homofílicos observados na atuação das organizações às quais eles pertencem. Esta opção se baseia no argumento de Georg Simmel, recentemente recuperado por Ann Mische, sobre a "dualidade de pessoas e grupos". Segundo a autora,

"o indivíduo pode ser visto como uma intersecção de todos os grupos aos quais ele ou ela pertencem; de maneira recíproca, grupos podem ser entendidos como a intersecção de todos os seus membros. [...] relações entre indivíduos são formadas pelos grupos aos quais eles pertencem conjuntamente, enquanto relações entre grupos são formadas pelos membros que eles compartilham" (MISCHE, 2008, p. 42-43 - tradução própria).

Com base neste argumento, assume-se que a homofilia nas redes associativas é correspondente à homofilia presente nas redes de relações dos indivíduos que participam de tais associações e vice-versa. Assim, através da análise de como a homofilia se (re)produz nestas últimas pode-se avançar na explicação de sua (re)produção nas primeiras.

Para desenvolver tais argumentos, este artigo está estruturado da seguinte forma: na próxima seção, é abordado o modelo de análise e os seus principais conceitos (distância social, homofilia, fronteiras sociais e simbólicas e invisibilização); depois, são apresentadas e discutidas a metodologia de análise de redes sociais (ARS) e a técnica de produção de dados informacionais conhecida como gerador de nomes, assim como as técnicas que permitiram explorar empírica e analiticamente os deslocamentos urbanos dos entrevistados; na penúltima seção, são apresentados dados sobre os bairros e as associações de moradores pesquisadas e, como tentativa de identificar a operação do mecanismo de invisibilização, são analisadas as redes de relações de dois indivíduos pesquisados e a distribuição territorial dos seus contatos, bem como os principais trajetos/percursos urbanos realizados por eles em suas vidas diárias. Por fim, encerra-se o artigo com algumas considerações finais. 
REDES- Revista hispana para el análisis de redes sociales

Vol.22,\#4, Junio 2012

http://revista-redes.rediris.es

\section{Quadro conceitual: distância social, homofilia, fronteiras sociais simbólicas e invisibilização}

O conceito de distância social apresenta uma extensa trajetória e diferentes acepções. Pode-se, de maneira geral, delimitar duas perspectivas teóricoepistemológicas a respeito da noção de distância social: uma marcadamente psicológica e outra mais propriamente sociológica ${ }^{3}$ (Lago; Ribeiro 2001), a qual será abordada neste artigo.

Buscando sintetizar o debate sociológico contemporâneo, Bottero (2005) ressalta que a apreciação dos estudos sobre estratificação permite delimitar, muito esquematicamente, duas perspectivas distintas sobre o conceito de distância social. Numa visão estrutural, a distância social é entendida em termos de localizações diferentes dentro de uma estrutura externa de estratificação. Num olhar relacional, a distância social é observada em termos de relações de proximidade ou distância em que a estratificação é conformada pelos padrões das vinculações existentes. Ademais, podem-se sublinhar outras diferenças fundamentais. Conforme resume a autora,

"nas perspectivas estruturais, grupos são definidos como socialmente distantes se eles são muito diferentes entre si (em termos de categorias de classe, gênero ou raça), enquanto que nas perspectivas relacionais eles são definidos como socialmente distantes se eles raramente se associam entre si. Grupos podem ser muito diferentes (pertencendo a diferentes categorias de classe ou raça), mas ainda assim serem socialmente próximos se eles se relacionam por amizade ou por parceria sexual regularmente" (BOTTERO, 2005, p.7 - tradução própria - grifos da autora).

Articulando estas perspectivas estrutural/posicional e relacional, Bourdieu (1996; 2005) percebe a sociedade como constituída por relações de proximidade e de separação que são, antes de tudo, relações hierárquicas. As posições geradas pela distribuição desigual do volume e da composição dos múltiplos tipos de capitais econômico, cultural, político, simbólico, social etc. - expressam as relações de dominação entre as classes e definem as posições ocupadas pelos indivíduos no espaço social. A distância social entre os atores sociais decorre, segundo Bourdieu, das relações das posições sociais nas quais eles estão inseridos.

\footnotetext{
3 Entre as abordagens clássicas de cunho mais designadamente psicológico se destacam autores como Bogardus (1925a; 1925b) e Park (1924). Para uma atualização crítica da proposta analítica construída por Bogardus ver Banton (1960). Sorokin (1973), por sua vez, ainda em meados dos anos 1920, estabelece uma perspectiva de caráter mais propriamente sociológico para o conceito de distância social.
} 
REDES- Revista hispana para el análisis de redes sociales

Vol.22,\#4, Junio 2012

http://revista-redes.rediris.es

Partindo das elaborações destes autores, neste artigo o conceito de distância social é construído levando em consideração tanto a sua dimensão estrutural - na qual a distância social decorre das diferenças de atributos entre os indivíduos - quanto a sua dimensão relacional - na qual a distância social é devida à ausência de relações entre os atores sociais. A partir desta conjugação entre distância social estrutural e distância social relacional, pode-se ressaltar o fato de que as pessoas que interagem socialmente também tendem a ser socialmente semelhantes em termos atributivos.

Segundo McPherson, Smith-Lovin e Cook (2001), isso significa que as distâncias em termos de características socioeconômicas e culturais se traduzem em distâncias relacionais - o que corresponde ao princípio de homofilia, segundo o qual similaridade social produz conexões sociais. Assim sendo, no entendimento de Bottero,

"o padrão de homofilia (o princípio de que semelhança gera relação) tem um grande impacto sobre as redes sociais. Semelhança social (não só em termos de status ocupacional, mas também ao longo de dimensões de raça, etnia, educação, idade, religião, atitudes, gostos e crenças) estrutura fortemente uma gama de rede de relações (de relações intensas e de longa duração como casamento/parceira e amizade, a laços mais curtos e circunscritos, tais como fornecer apoio a carreira, a 'conhecer alguém', ou aparecer junto no espaço público)" (BOTTERO, 2005, p.166 - tradução própria - grifos da autora).

O outro conceito fundamental para a construção desta pesquisa é o de fronteira. Em anos recentes, a noção de fronteira tem ocupado um papel chave em diferentes áreas das ciências sociais (LAMONT; MOLNÁR, 2002; PACHUCKI; PENDERGRASS; LAMONT, 2007). Pode-se, antes de qualquer coisa, arguir, conforme Tilly (2004; 2005), que as fronteiras "nos" separam "deles". Elas interrompem, dividem, circunscrevem e segregam a distribuição de populações no interior das sociedades.

Saint-Martin, Rocha e Heredia (2008) e Labache e Saint-Martin (2008) realçam, por sua vez, a relação entre distância social e a produção de fronteiras sociais. Para as autoras, o conceito de fronteira constitui uma ferramenta teórico-metodológica particularmente pertinente para pesquisar as múltiplas formas de manutenção e de recomposição da distância entre grupos em sociedades atravessadas por profundas desigualdades e divisões. Já Lamont e Molnár (2002) destacam a relação entre fronteiras e a produção de semelhanças e de diferenças. Em suas palavras, "a noção de fronteiras é crucial para analisar como os atores sociais constroem grupos como similares e diferentes e como isso divide seus entendimentos e suas responsabilidades para com tais grupos" (Lamont; Molnár, 2002, p.187 - tradução própria). 
REDES- Revista hispana para el análisis de redes sociales

Vol.22,\#4, Junio 2012

http://revista-redes.rediris.es

Lamont e Molnár (2002) distinguem duas dimensões constitutivas do conceito de fronteira. As fronteiras simbólicas se referem a distinções conceituais feitas pelos atores sociais para categorizar objetos, pessoas, práticas etc. Elas constituem ferramentas pelas quais indivíduos e grupos disputam e entram em acordo sobre definições do mundo social. Ao investigá-las é possível capturar as dinâmicas das relações de como os grupos competem na produção, difusão e institucionalização de sistemas alternativos de princípios de classificação e de demarcação. Já as fronteiras sociais correspondem, por sua vez, a formas objetivadas de diferenças manifestadas no acesso e distribuição desiguais de recursos e de oportunidades. Elas são reveladas através dos padrões estáveis de associação e interação entre os indivíduos.

Sustenta-se, portanto, a existência de uma interdependência entre as posições sociais ocupadas pelos agentes na estrutura do espaço social e as suas estruturas de relações cotidianas. Os processos de (re)produção de fronteiras sociais e simbólicas e os mecanismos a eles associados explicariam, então, como as distâncias estruturais traduzem-se muito frequentemente em distâncias relacionais entre os indivíduos.

No entanto, a busca dos "mecanismos da homofilia" implica ir além da possível e provável associação causal entre distância estrutural e distância relacional e a consequente produção de conexões sociais homofílicas. Nesse sentido, coloca-se a necessidade de desvendar quais são os mecanismos que constituem o que é denominado pela literatura sociológica como a "caixa-preta" entre uma causa (input) e um efeito (outcome) (Hedström; Swedberg, 1996; Mahoney, 2001; 2003; Mayntz, 2004). Desse modo, esta proposta de análise tem por objetivo central "abrir" a "caixa-preta" do processo de (re)produção de vínculos sociais homofílicos no associativismo urbano, analisando, mais especificamente, a invisibilização como um dos mecanismos explicativos de tal processo. O Quadro 1 sistematiza as associações entre os conceitos que sustentam o argumento desenvolvido. 


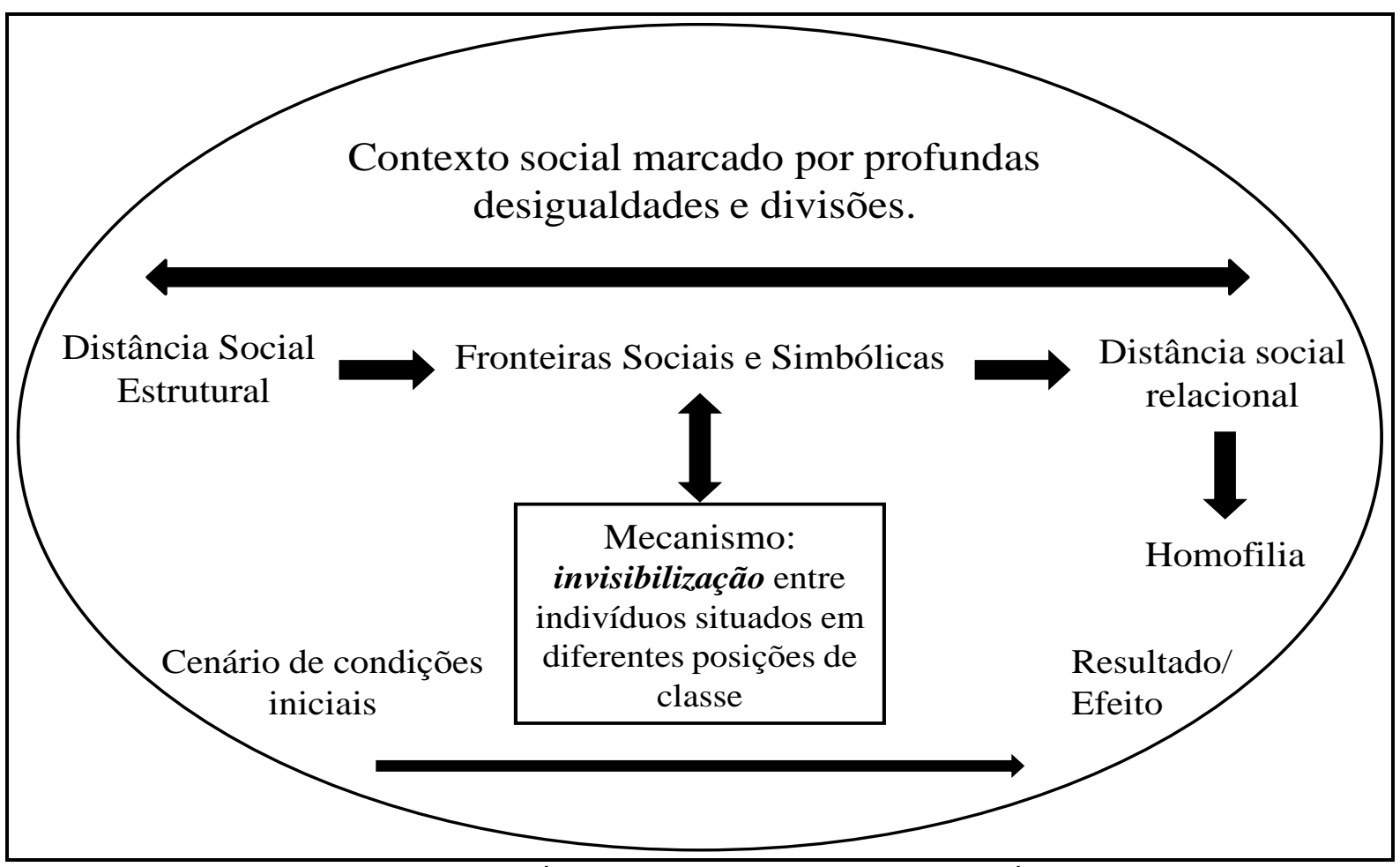

Quadro 1: Relações entre conceitos e variáveis que sustentam a proposta de análise. Fonte: elaboração dos autores.

Para Mayntz (2004), as análises baseadas em mecanismos causais procuram explicar como e por quais passos intermediários um determinado resultado segue de um cenário de condições iniciais. Se uma causa produz um efeito sem passos intermediários, certamente, nenhum mecanismo está envolvido e, neste caso, a própria relação de causa-efeito corre o risco de ser uma tautologia. Hedström e Swedberg (1996), por sua vez, empregam o termo mecanismo para se referirem ao componente de um processo social que conecta uma causa (input) a um efeito (outcome). Isso pode ser formalmente expresso da seguinte forma: $I-M-O$. $O$ mecanismo $M$ serve para explicar a relação observada entre as condições iniciais específicas $I$ e o resultado específico $O$.

A partir das ponderações acima apresentadas, este trabalho busca explorar a "caixa-preta" que seria, hipoteticamente, constituída pelo mecanismo de invisibilização entre agentes situados em diferentes posições de classe. Nesta pesquisa com associações de moradores de bairro de classe média, mais especificamente, tal mecanismo estaria associado à invisibilização daqueles indivíduos situados em posições socialmente inferiores por parte daqueles situados em posições superiores no espaço social. Visa-se, em outras palavras, investigar como ocorre a invisibilização de indivíduos e grupos situados em posições inferiores entre indivíduos que atuam em associações formadas por (e/ou que buscam 
REDES- Revista hispana para el análisis de redes sociales

Vol.22,\#4, Junio 2012

http://revista-redes.rediris.es

representar) segmentos em posições superiores. É essa invisibilização, segundo o argumento aqui sustentado, que explica, em grande medida, a configuração homofílica do associativismo urbano.

Conforme dito anteriormente, a construção teórico-analítica do mecanismo invisibilização se dá em duas dimensões fundamentais, as quais demandam procedimentos de operacionalização metodológica específicos. A primeira dimensão diz respeito ao fato de que indivíduos situados em determinadas posições de classe estão, em grande medida, ausentes das redes de relações consideradas significativas pelos (e, assim, também dos espaços de sociabilidade frequentados pelos) agentes sociais localizados em outras posições no espaço social. Essa primeira dimensão da invisibilização está associada, dessa forma, à ausência de laços sociais mais próximos e constantes entre agentes posicionados desigualmente no espaço social. Para dar conta de tal dimensão, será empregada a metodologia de ARS, operacionalizada pelas técnicas de produção de informações relacionais conhecidas como gerador de nomes e name interpreters, conforme será detalhado na próxima seção.

Já a segunda dimensão do mecanismo de invisibilização está associada a padrões socialmente segmentados de estruturação dos trajetos urbanos realizados pelos indivíduos em seu cotidiano. Através da exploração empírica destes percursos pela cidade, busca-se identificar padrões de deslocamento, os quais, hipoteticamente, estariam conformados socialmente. Assim, ao se investigar os caminhos urbanos através dos quais os indivíduos (os aqui investigados se situam em posições superiores no espaço social) se deslocam pela cidade, seria possível conhecer os lugares que conformam a compreensão/visão que eles têm dos espaços urbanos nos quais constroem o seu cotidiano.

Além disso, é igualmente importante investigar de onde partem - neste estudo o ponto de origem dos percursos era o endereço de residência do entrevistado - e para onde vão os atores sociais dentro do espaço da cidade. Desse modo, seria possível acessar a imagem mental construída pelos indivíduos dos (e em) seus deslocamentos diários. Imagem essa que tenderia a omitir e/ou, no limite, ocultar os grupos inferiormente situados no espaço social, no caso aqui investigado. $\mathrm{Na}$ próxima seção são discutidas a metodologia e a técnica de pesquisa que foram empregadas para investigar os trajetos urbanos dos entrevistados. 
REDES- Revista hispana para el análisis de redes sociales

Vol.22,\#4, Junio 2012

http://revista-redes.rediris.es

\section{Metodologia e técnica de pesquisa}

A análise de redes sociais (ARS) é uma metodologia de pesquisa que procura identificar e analisar os padrões e as dinâmicas dos vínculos sociais. Ela não corresponde a uma teoria social propriamente dita, mas, sem dúvida, compartilha com a chamada sociologia relacional os seus pressupostos epistemológicos e ontológicos. Assim, a ARS oferece uma ferramenta metodológica para operacionalização dos pressupostos analíticos do que se costuma qualificar de uma abordagem relacional do mundo social. Ao mesmo tempo, não é correto definir a ARS apenas como um conjunto restrito de métodos e técnicas de pesquisa (Wellman, 1983; Emirbayer, 1997). Isso porque, conforme destaca Boissevain (1979), a análise de redes como um instrumento de investigação tem significativas implicações teóricas, embora não constitua uma teoria social. Para o autor,

"ela é um instrumento analítico que considera círculos de parentes e amigos, coalizões, grupos e casas de negócios, complexos industriais, e, até mesmo, Estados-Nação como dispersões de pontos conectados por linhas que formam redes. [...] A análise de redes faz questões sobre quem está ligado a quem, o conteúdo das ligações, o padrão que elas formam, a relação entre o padrão e comportamento e a relação entre o padrão e outros fatores sociais. Isso tem implicações teóricas na medida em que ela forma parte de uma mudança paradigmática para além do estrutural-funcionalismo" (Boissevain 1979, p.392 - tradução própria).

Emirbayer (1997) e Emirbayer e Goodwin (1994) estabelecem importante correspondência epistemológica e metodológica entre a sociologia relacional e a ARS. Para os autores, a abordagem de redes investiga as restrições e as possibilidades de relações entre atores sociais dentro de um sistema. Por isso, ela fornece uma ligação entre seus os insights teóricos e as suas contribuições para o desenvolvimento da pesquisa empírica. Nesse sentido, Emirbayer (1997) destaca que a ARS é a perspectiva mais desenvolvida e mais amplamente empregada para a investigação da estrutura social. Para o autor, a análise de redes

"não é fundamentalmente uma teoria ou mesmo um conjunto de técnicas de pesquisa complicadas, mas, ao invés, uma nova família compreensiva de estratégias analíticas, um paradigma para o estudo de como recursos, bens e, até mesmo, posições circulam através de figurações particulares de laços sociais" (EMIRBAYER, 1997, p.298 - tradução própria).

Assim, a ARS e a sociologia relacional compartilham, epistemológica e ontologicamente, o pressuposto de que as relações sociais têm centralidade na análise dos fenômenos sociais. Para ambas, as relações entre os atores sociais são fundamentais na explicação social e, assim, elas criticam os modelos de análise que focam exclusivamente nos atributos (tais como as características socioeconômicas) 
REDES- Revista hispana para el análisis de redes sociales

Vol.22,\#4, Junio 2012

http://revista-redes.rediris.es

individuais. As unidades básicas de análise são as relações sociais entre os atores sociais. Desloca-se, portanto, a investigação social dos atributos individuais para as relações entre os agentes sociais ${ }^{4}$. As características das relações explicam a realidade social. Nesse sentido, o que as pessoas são, pensam e fazem são produtos das relações estabelecidas entre elas. Conforme explica Marques,

"de acordo com essa vertente de análise [a sociologia relacional], as instituições, a estrutura social e as características de indivíduos e grupos são cristalizações dos movimentos, trocas e "encontros" nas múltiplas e intercambiantes redes de relações ligadas e superpostas. A matéria-prima das ciências sociais seria, portanto, o conjunto das relações, vínculos e trocas entre entidades, e não suas características" (Marques 1999, p.47).

Para compreender como opera o mecanismo invisibilização na rede de relações sociais de indivíduos participantes das associações de moradores de bairro de classe média pesquisadas, empregou-se a metodologia de ARS. A técnica de produção de informações relacionais denominada de gerador de nomes (name generator) possibilitou construir a rede de relações dos entrevistados. Essas redes individuais foram levantadas através de duas questões vinculadas aos contextos da vida pessoal e associativa de cada um dos pesquisados.

Nas discussões metodológicas acerca da ARS há duas formas básicas de investigar os padrões e as dinâmicas das redes de relações sociais: as redes individuais e as redes totais (MARQUES, 2010). Quando o objetivo é analisar os padrões e as dinâmicas dos vínculos das redes individuais, uma das principais questões a ser respondida diz respeito à definição do que se compreende por rede pessoal (personal network) e por rede egocentrada (ego-network, egocentric network, egocentered network). Essas duas abordagens das redes individuais incluem os contatos de sociabilidade mais próximos de cada indivíduo. Já nas chamadas redes totais, o foco da investigação empírica recai sobre o estudo de redes inteiras ou parciais em contextos sociais específicos - como, por exemplo, os padrões e as dinâmicas de relações internas e externas em agências estatais e nas suas políticas (Marques, 1999; 2006a).

Segundo Marques (2006b; 2009; 2010), a maior parte das investigações empíricas de redes individuais considera somente os laços sociais diretos de um agente social (ego) e as vinculações existentes entre os seus contatos primários (alters) - ou seja, redes egocentradas. Contudo, para o autor, tal escolha metodológica confina a sociabilidade dos atores sociais aos seus contatos primários, enquanto que a

\footnotetext{
4 Ao invés de uma visão de oposição entre atributos e relações, a tendência contemporânea é a combinação destes em modelos de análise mais complexos.
} 
REDES- Revista hispana para el análisis de redes sociales

Vol.22,\#4, Junio 2012

http://revista-redes.rediris.es

opção pelas redes pessoais não restringe previamente a abrangência da rede pesquisada. Então, Marques toma como estratégia metodológica as "redes pessoais entendidas como os contextos de relações que os indivíduos reconhecem como seus, mas que podem ou não estar ligados diretamente a eles" (MARQUES, 2010, p.50).

Para Marques (2006b; 2009; 2010), é importante notar que rede pessoal não deve ser entendida como sinônimo de rede egocentrada, como parece acontecer algumas vezes na literatura internacional. Em geral, as redes pessoais são definidas como uma rede de relações descrita do ponto de vista de um ator social (ego) (Marin; Hampton, 2007; Wellman, 1983; Boissevain, 1974). Considera-se, nesta investigação, imprescindível definir adequadamente o que se compreende por rede pessoal - já definida acima segundo a construção feita por Marques (2010) - e por rede egocentrada. Assim, redes egocentradas dizem respeito "[...] apenas as relações diretas do indivíduo e as eventuais relações entre esses contatos primários, ou seja, apenas as relações diretas e não mediadas a no máximo um passo de distância do ego [...]" (Marques, 2010, p.49).

Sem dúvida, as ponderações feitas por Marques $(2009 ; 2010)$ sobre os limites e problemas das redes egocentradas são corretas e relevantes para o desenvolvimento da ARS no Brasil, sobretudo quando a atenção incide sobre indivíduos em situação de pobreza. Isso porque, conforme destaca o autor, "uma parcela importante da sociabilidade que influencia a pobreza e as condições de vida ocorre a distâncias maiores do ego do que do seu entorno imediato" (MARQUES, 2009, p.478).

Contudo, neste trabalho optou-se por investigar redes egocentradas. Tal opção metodológica se fundamenta em um ponto principal. Ao que tudo indica, o estudo de redes egocentradas permite compreender, adequadamente, o modo como opera - mecanismo invisibilização nas redes de relações. Isso porque possibilita evidenciar empiricamente com quem indivíduos situados numa posição social de classe média costumam, nos seus laços sociais cotidianos, relacionar-se, discutir questões relevantes e conversar sobre os problemas do bairro, no caso de atores sociais participantes de associações de moradores. É preciso, portanto, ter claro que as redes egocentradas lançam luz sobre o que é fundamental para investigar o mecanismo de invisibilização. Ou seja, redes egocentradas possibilitam identificar e analisar aqueles vínculos sociais mais íntimos, mais próximos e mais visíveis de um determinado ego. 
REDES- Revista hispana para el análisis de redes sociales

Vol.22,\#4, Junio 2012

http://revista-redes.rediris.es

No estudo das redes pessoais e das redes egocêntricas uma das técnicas de coleta de dados mais comumente empregadas é a que se convencionou denominar de gerador de nomes (name generators). Através dela é possível identificar os contatos primários (alters) de um determinado ator social (ego), bem como as relações entre os nós que compõem a rede centrada em ego.

O gerador de nomes pode ser utilizado através de surveys ou de entrevistas. Aos entrevistados são feitas uma ou mais questões, as quais têm por objetivo obter uma lista de nomes dos seus contatos primários. Em geral, ao entrevistado é requerido listar as pessoas "com quem conversou sobre assuntos importantes". Esta questão pode ser limitada a um determinado contexto social (família, trabalho, atividades associativas etc.) e a um período de tempo - como, por exemplo, nos últimos seis meses. Em seguida, o entrevistado informa quais dos seus contatos mantêm alguma relação entre si. Através de tais procedimentos é obtida a estrutura da rede centrada em um ator social.

Contudo, o referido procedimento de construção de informações relacionais não se encerra no gerador de nomes. Junto a essa técnica, pode-se acrescentar o que a literatura denomina de name interpreters. Esta técnica consiste, basicamente, em questões que visam produzir informações socioeconômicas sobre os contatos primários de ego (Marin; Hampton, 2006; Bidart; Charbonneau, 2007; Vehovar et. al., 2008; Burt, 2009). Em linhas gerais, name generators e name interpreters possibilitam identificar e analisar a estrutura de uma rede de relações sociais centrada em um determinado ator social, bem como ter uma delimitação aproximada da posição social dos nós que compõem a sua rede social.

Portanto, tais técnicas de produção de dados relacionais permitem dar conta da investigação de como opera na realidade social o mecanismo de invisibilização das classes populares pelas classes médias, uma vez que uma das suas duas dimensões, apresentadas precedentemente, está associada às seguintes questões: 1) com quem os indivíduos situados numa posição social de classe média costumam se relacionar mais frequentemente?; e 2) que posição social ocupam os indivíduos e grupos que são "vistos" e/ou "notados" pelos agentes sociais posicionados nas classes médias?

Para dar conta da segunda dimensão do mecanismo de invisibilização - qual seja: a invisibilização de indivíduos situados em posições sociais inferiores nos trajetos urbanos daqueles agentes sociais mais bem situados na hierarquia social -, foram realizadas entrevistas semiestruturadas, baseadas em duas questões sobre os deslocamentos dos entrevistados dentro do seu bairro de residência e dentro da 
REDES- Revista hispana para el análisis de redes sociales

Vol.22,\#4, Junio 2012

http://revista-redes.rediris.es

cidade de Porte Alegre. Aos indivíduos pesquisados foi solicitado traçar em um mapa até três percursos dentro do bairro e em outro mapa até três trajetos dentro da cidade, bem como fazer comentários sobre tais percursos.

Essas entrevistas visavam explorar duas situações fundamentais para a compreensão de como opera o mecanismo de invisibilização na realidade social. Em primeiro lugar, procurou-se identificar os lugares mais frequentados pelos entrevistados no seu cotidiano. Ou seja, para onde vão os indivíduos pesquisados quando saem de suas casas. Tais informações pretendiam trazer à tona quais locais são frequentados pelos indivíduos que integram as associações de bairro de classe média pesquisadas. A ideia básica era, ao identificar esses lugares, aferir que lugares são esses. Conforme pondera Bottero, "é o modo pelo qual nossas vidas diárias são afetadas por nossa localização no espaço social que produz padrões de homofilia e homogamia. São encontros classificados que conduzem a cruzamentos classificados" (Bottero, 2005, p.170 - grifos da autora - tradução própria).

Em segundo lugar, visou-se identificar como são os deslocamentos realizados pelos entrevistados. A partir de tais informações, o objetivo era identificar por quais bairros, regiões, ruas, avenidas, parques e/ou praças passam os entrevistados em seus deslocamentos cotidianos. Se, conforme coloca Bottero (2005), as áreas geográficas são ordenadas por atributos (raça, renda etc.) e, portanto, tendem a ser compostas por indivíduos similares com relação aos seus atributos sociais, levarão em conta os entrevistados tal segmentação sócio-geográfica ao realizar/escolher seus trajetos? Ou, ainda, perceberão essa classificação sóciogeográfica em seus caminhos urbanos? Um dos propósitos do emprego de tal técnica de pesquisa é acessar a imagem mental construída pelos indivíduos dos seus percursos cotidianos. Isso porque, conforme sublinha Lynch, "cada cidadão tem vastas associações com alguma parte de sua cidade, e a imagem de cada um está impregnada de lembranças e significados" (LYNCH, 2006, p.1).

\section{Identificando o mecanismo de invisibilização nas redes sociais}

Para analisar a sustentabilidade empírica do argumento proposto neste trabalho, serão analisadas as redes egocentradas de dois indivíduos atuantes em associações de moradores de dois bairros que apresentam elevados indicadores socioeconômicos. No primeiro caso explorado (da AM_1), o bairro se situa na $U^{5} H^{5}$

\footnotetext{
${ }^{5}$ UDH: Unidade de Desenvolvimento Humano: é a agregação de setores censitários que atendem às exigências do IBGE para produção de indicadores; e, além disso, é uma aproximação dos bairros constituídos por lei ou reconhecidos pela identificação popular.
} 
REDES- Revista hispana para el análisis de redes sociales

Vol.22,\#4, Junio 2012

http://revista-redes.rediris.es

que possuía o IDH ${ }^{6}$ mais elevado da cidade de Porto Alegre - 0,977 - no ano 2000. No segundo exemplo analisado (da AM_2), o bairro se situa em duas UDHs que possuíam, no ano 2000, IDH entre os mais elevados da cidade de Porto Alegre 0,963 e 0,943 (Prefeitura/Secretaria de Coordenação Política e governança local et. al., 2008).

\section{O caso da Associação de Moradores 1 (AM_1)}

Com base nas informações obtidas, a primeira fundação da AM_1 aconteceu no início da década de 1960. Até meados dos anos 1970, a associação se manteve atuante. Segundo um dos moradores mais antigos a atuar na AM_1, naquele período a associação era muito forte, pois conseguia mobilizar muitos moradores. Porém, após um longo período sem atuação, é somente entre 2007 e 2008 que AM_1 retoma suas atividades. Atualmente, as principais questões trabalhadas pela associação são: o fim das "algazarras noturnas", a melhoria na segurança, a preservação da "qualidade de vida" frente ao avanço de grandes edificações no bairro, a melhoria no trânsito e os problemas causados pelos mendigos no bairro.

O sociograma abaixo retrata a rede egocentrada de um dos indivíduos mais atuantes na AM_1:

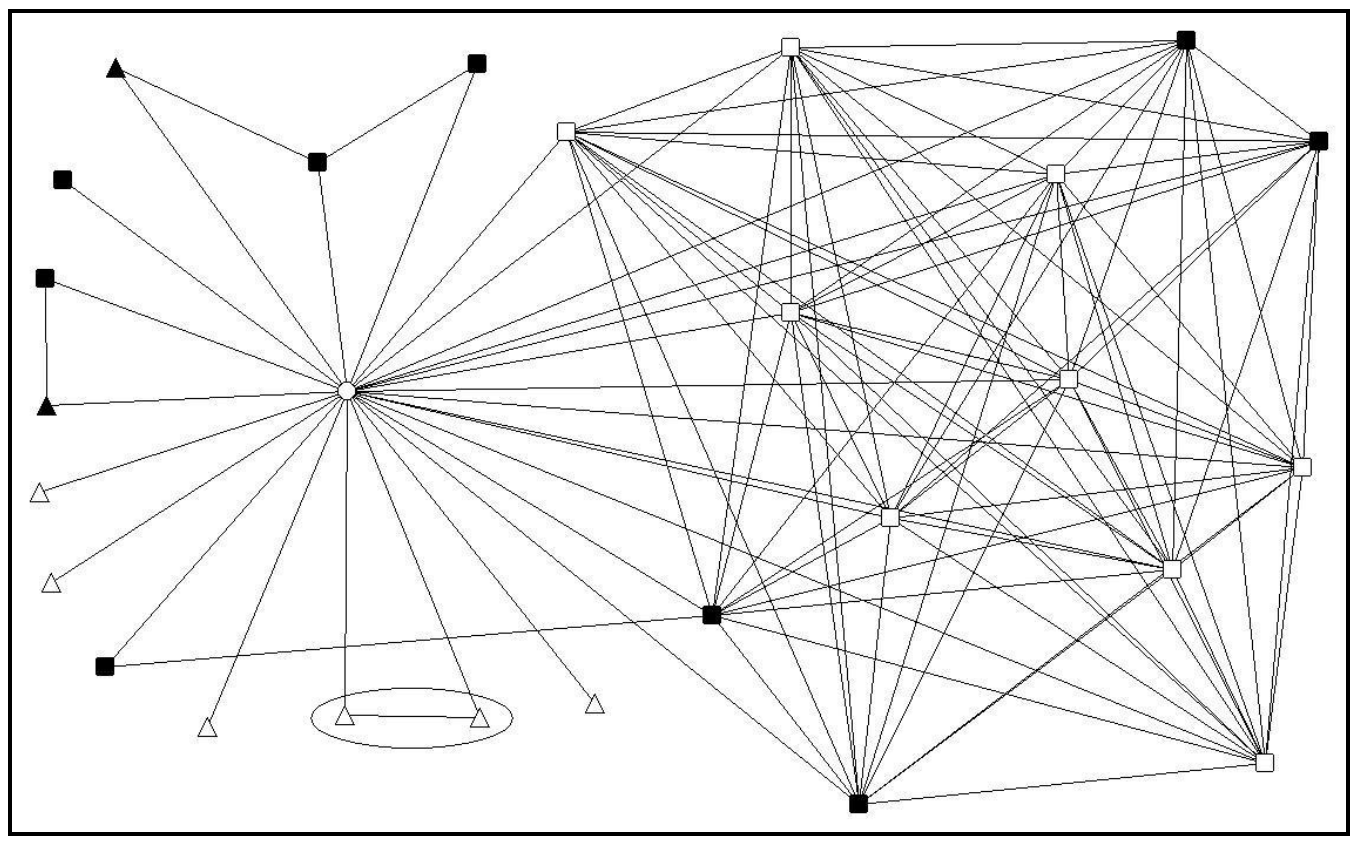

Sociograma 1. Rede egocentrada_001. Fonte: elaboração dos autores a partir do gerador de nomes.

\footnotetext{
${ }^{6} \mathrm{IDH}$ : Índice de Desenvolvimento Humano. O IDH varia em uma escala de 0 a 1 , sendo que quanto mais próximo de 1 , melhor será a qualidade de vida de um país, região, cidade ou, neste caso, de uma UDH.
} 
REDES- Revista hispana para el análisis de redes sociales

Vol.22,\#4, Junio 2012

http://revista-redes.rediris.es

Este indivíduo apresenta as seguintes características: homem, 44 anos, pósgraduado e com envolvimento ativo na associação desde 2008. Além disso, atua profissionalmente como assessor e consultor em planejamento estratégico e gestão para instituições sem fins lucrativos e organismos internacionais. Em termos da caracterização dos 26 alters que compõem a rede egocentrada_001, observa-se que são doze mulheres e quatorze homens. A grande maioria dos alters - 21 indivíduos - possui ensino superior completo. Em termos de inserção profissional dos alters, as informações são: três professores, dois engenheiros, cinco comerciantes, dois funcionários públicos, dois vereadores, um artista plástico, um médico, um advogado, um arquiteto, uma fisioterapeuta, uma pedagoga, uma jornalista, uma ambientalista, um designer e publicitário, um desenhista e urbanista e uma psicóloga?.

No que diz respeito ao bairro de residência dos seus alters, o entrevistado forneceu informações para 24 deles. A tabela 1, abaixo, informa o bairro, o número de residentes em cada bairro, o rendimento médio em salários mínimos dos responsáveis por domicílio e o número médio de anos de estudo dos responsáveis por domicílio. Observa-se, em primeiro lugar, que a quase totalidade dos seus contatos reside em bairros com indicadores socioeconômicos bastante elevados, entre os mais altos da cidade de Porto Alegre. Além disso, a maioria das suas conexões se localiza geograficamente no seu bairro de residência (14 indivíduos).

\footnotetext{
${ }^{7}$ Um dos alters não teve sua profissão definida, uma vez que o entrevistado o identificou apenas como "líder comunitário".
} 
REDES- Revista hispana para el análisis de redes sociales

Vol.22,\#4, Junio 2012

http://revista-redes.rediris.es

\begin{tabular}{|c|c|c|c|}
\hline Bairro & $\begin{array}{c}\text { Número de } \\
\text { alters } \\
\text { residentes }\end{array}$ & $\begin{array}{l}\text { Rendimento médio em } \\
\text { salários mínimos dos } \\
\text { responsáveis por } \\
\text { domicílio - Bairro* }\end{array}$ & $\begin{array}{c}\text { Número médio de anos } \\
\text { de estudo dos } \\
\text { responsáveis por } \\
\text { domicílio - Bairro* } \\
\end{array}$ \\
\hline Auxiliadora & 14 & 19,9 & 12,75 \\
\hline Moinhos de Vento & 2 & 29,7 & 13,18 \\
\hline Partenon & 2 & 8,1 & 8,90 \\
\hline Centro & 2 & 12,8 & 12,04 \\
\hline Tristeza & 1 & 16,9 & 11,39 \\
\hline Mont' Serrat & 1 & 24,4 & 12,81 \\
\hline Nonoai & 1 & 9,4 & 9,26 \\
\hline $\begin{array}{l}\text { Parque Santa Fé } \\
\text { (Rubem Berta) }\end{array}$ & 1 & 6,0 & 8,36 \\
\hline \multicolumn{2}{|c|}{ Porto Alegre } & 9,9 & 9,07 \\
\hline
\end{tabular}

Tabela 1. Perfil sócio-geográfico da rede egoncentrada_001.Fonte: elaboração dos autores a partir do gerador de nomes. *Fonte: Fonte: IBGE - Censo Demográfico - 2000.

Chama a atenção o fato de que apenas um dos nós da rede egocentrada_001 reside em um bairro que apresenta indicadores socioeconômicos, significativamente, baixos, sobretudo em comparação aos demais alters. Contudo, ao se verificar as condições sociais e econômicas de tal conexão, percebe-se que ela ocupa uma posição superior na hierarquia social, visto que tem ensino superior completo, exercendo a profissão de médico. Em especial, o indicador de escolaridade deste contato contrasta com o numero médio de anos de estudos (que é de 8,36$)$ dos responsáveis por domicílio do seu bairro de residência.

Com relação ao padrão e à dinâmica da rede social analisada, é interessante observar que o próprio entrevistado delimitou a existência de três "grupos" diferentes. O primeiro deles é formado pelos nós vinculados à sua atuação na associação - os quais estão assinalados por quadrados brancos. Este grupo constitui um verdadeiro clique, uma vez que todos os nós estão diretamente relacionados entre si.

O segundo recorte diz respeito aos seus laços sociais cotidianos - amigos e familiares -, os quais estão marcados por triângulos brancos. Observa-se que este é um segmento relativamente pequeno (apenas seis nós), que não estabelece 
REDES- Revista hispana para el análisis de redes sociales

Vol.22,\#4, Junio 2012

http://revista-redes.rediris.es

relações com os outros nós que compõem a rede de ego e nem entre si (com exceção dos dois alters circulados na parte inferior do sociograma 1 ).

Por fim, há um conjunto de nós com o qual ele conversa sobre os problemas e as demandas do seu bairro de residência - tais nós são apontados por quadrados e triângulos ${ }^{8}$ pretos. Este segmento apresenta uma conformação relacional mais heterogênea: de um lado, identificam-se alguns nós isolados e pequenos cliques; de outro, existem vários nós conectados a nós do clique da associação.

Pode-se inferir, a partir dos dados apresentados, a significativa presença de relações sociais homofílicas na rede egocentrada_001. De um lado, os nós que ego identifica como sendo suas relações sociais significativas compartilham com ele atributos sociais similares, indicando uma alta proximidade posicional. De outro lado, uma parte significativa de sua rede apresenta um elevado nível de conexão entre os alters, indicando uma alta proximidade relacional.

Contudo, a homofilia presente na rede egocentrada elaborada a partir do gerador de nomes não significa que o entrevistado não mantenha contatos ou mesmo ações conjuntas com indivíduos e grupos sociais ocupantes de posições distintas no espaço social. Justamente por ser um agente social envolvido em diversas atividades associativas - além de suas ações através da associação, sua atividade profissional de assessoria e consultoria o coloca em contato com diversas organizações sociais - é provável que ele estabeleça constantemente contatos com indivíduos e grupos posicionados em outras classes sociais. Isso fica claro quando o entrevistado, ao ser questionado sobre o seu contato com associações de regiões da periferia de Porto Alegre, faz o seguinte relato:

"ele [este contato com] é envolvido mais com o meu trabalho na associação de moradores. Porque a associação de moradores, a AMA, porque ela, a partir do momento em que se instituiu e ela se re-fundou, ela passou a integrar os diferentes espectros de inter-relação no município. Então, eu vou citar: nós participamos do Fórum de Entidades que participou, integrou o grupo de revisão do Plano Diretor de Porto Alegre; nós integramos o Conselho Municipal de Desenvolvimento Urbano e Ambiental - eu no caso, como primeiro suplente da Região 1 (...); nós integramos ainda, no caso, alguns moradores integraram o Movimento em Defesa da Orla [do Guaíba], que teve uma atuação destacada naquela questão do Pontal do Estaleiro. Então, essa minha relação fez com que nesses espaços eu encontrasse essas diversas entidades co-irmãs e de diferentes áreas e de diferentes regiões de Porto Alegre".

\footnotetext{
${ }^{8}$ Os triângulos indicam dois vereadores - um do PSol e outro do PP - com quem ego se relaciona.
} 
REDES- Revista hispana para el análisis de redes sociales

Vol.22,\#4, Junio 2012

http://revista-redes.rediris.es

Esta relativa discrepância entre a rede de relações significativas para o entrevistado, identificada a partir do gerador de nomes, e sua efetiva inserção relacional (muito mais ampla e socialmente diversificada) constitui-se em um importante indicador do mecanismo de invisibilização. Os contatos com indivíduos em posição social inferior, que o entrevistado estabelece a partir de sua militância associativa e/ou de sua atividade profissional, não são identificados por ele como significativos ou, no limite, simplesmente não são percebidos. Ou seja, tornam-se invisíveis. Esta invisibilidade obstaculiza a possibilidade de se constituírem relações significativas entre ego e seus contatos situados em posição social inferior, contribuindo para a reprodução da homofilia de sua rede relacional.

No que tange à segunda dimensão do mecanismo de invisibilização, serão explorados, abaixo, seis trajetos urbanos realizados por este entrevistado: três percursos dentro do seu bairro de residência e outros três itinerários no âmbito mais geral da cidade. Esses seis deslocamentos urbanos têm como ponto de partida o local de moradia do entrevistado. Vale ressaltar, ainda, que ele não costuma utilizar automóvel para se deslocar pelo bairro ou pela cidade. Os percursos dentro do bairro são realizados a pé. Já os deslocamentos pela cidade são feitos, em geral, de ônibus e, eventualmente, de automóvel.

O primeiro trajeto urbano tem como destino uma pequena praça (cercada por grades) localizada ao lado da paróquia do bairro. Este descolamento é realizado com o objetivo de levar a filha brincar. O ponto de chegada do segundo trajeto é a Escola Estadual Daltro Filho, onde estuda uma de suas filhas. O terceiro deslocamento pelo bairro é realizado para ir ao supermercado.

No que concerne aos principais deslocamentos pela cidade, os três destinos explorados são bem distintos. O primeiro deles é feito em direção à região central de Porto Alegre, passando pela Praça da Matriz, até a Assembleia Legislativa, onde o entrevistado participa das reuniões semanais do Fórum de Entidades (o qual se organizou em torno da revisão do Plano Diretor). Ainda com relação a este primeiro trajeto na escala da cidade, é importante ressaltar as considerações feitas pelo entrevistado sobre o Fórum de Entidades. Entre as entidades que participam deste espaço, ele mencionou a Associação dos Moradores do Centro, a Associação Moinhos de Vento, a Associação dos Amigos e Moradores do Bairro Independência, a Associação dos Moradores do Bairro Ipanema, a Associação do Bairro Tristeza e, nas suas palavras, "associações que são movimentos ligados ao pessoal do OP: 
REDES- Revista hispana para el análisis de redes sociales

Vol.22,\#4, Junio 2012

http://revista-redes.rediris.es

Orçamento Participativo" ${ }^{\prime 9}$. Sobre a presença destes últimos, ele informou que são representantes individuais, os quais são membros e conselheiros do OP. Eles participam, segundo o entrevistado, porque as discussões do Plano Diretor implicam diretamente no contexto de toda a cidade. Contudo, os indivíduos ligados ao OP, na sua compreensão não mantêm uma presença frequente, mas sim esporádica.

O segundo deslocamento tem como objetivo buscar as filhas do primeiro casamento, tendo como destino o bairro Santo Antônio. Segundo o entrevistado, é possível perceber significativas mudanças durante o percurso. Assim, os bairros Rio Branco e Santa Cecília apresentam características sociais, demográficas, morfológicas e, até mesmo, de sociabilidade bastante distintas em relação aos bairros Santana e Santo Antônio, os quais se localizam depois da Avenida Ipiranga. Neste ponto do trajeto, o entrevistado localiza uma clara fronteira entre os dois conjuntos de bairros. Essas diferenças são de poder aquisitivo, de tipo de residência e de relação dos moradores com as ruas, pois, na visão do entrevistado, não há encontros de sociabilidade, não há parques como, por exemplo, o Parque Moinhos de Vento (parque localizado nos arredores do bairro de residência deste entrevistado). Contudo, o bairro Santo Antônio, apesar de apresentar características distintas e indicadores sociais mais baixos em relação aos outros bairros frequentados pelo entrevistado, possui áreas com presença de segmentos de renda elevada.

Por fim, o terceiro deslocamento na escala da cidade tem como destino o bairro Ipanema, na zona sul de Porto Alegre. O entrevistado realiza tal percurso por causa do seu trabalho de assessoria de gestão para entidades sem fins lucrativos. No caso em questão, essas entidades são o Clube do Professor Gaúcho e a Rádio Ipanema Comunitária, a qual é uma concessão pública dada à Associação dos Moradores do Bairro Ipanema. Segundo a compreensão do entrevistado, há uma mudança radical de características ao longo do trajeto. A zona sul carece, para ele, de uma séria de obras de pavimentação. Nesses bairros há a predominância de áreas verdes, sendo esses locais alvos de especulação imobiliária. O que resulta numa disputa de espaços, segundo informou o entrevistado, entre grupos ambientalistas, os quais defendem a preservação das áreas de mata atlântica ali existentes, e grupos privados ligados a construção civil.

\footnotetext{
${ }^{9}$ É interessante observar que todas as Associações identificadas individualmente pelo entrevistado são Associações de bairros de classe média, enquanto as "Associações do OP", referidas pelo entrevistado de forma indistinta, tendem a ser Associações de bairros e vilas populares da cidade.
} 
REDES- Revista hispana para el análisis de redes sociales

Vol.22,\#4, Junio 2012

http://revista-redes.rediris.es

A partir da caracterização dos deslocamentos urbanos realizada nos parágrafos anteriores, percebe-se que os destinos dos trajetos (para onde vai o entrevistado) tendem a ser espaços da cidade pouco diversificados socialmente, nos quais os contatos são geralmente estabelecidos com indivíduos que ocupam uma posição social similar a do entrevistado. Mesmo nos casos nos quais ocorre uma interação com indivíduos de bairros e vilas populares, como no Fórum de Entidades que se reúne na Assembléia Legislativa, o entrevistado mencionou com muita rapidez e facilidade o nome das entidades e lideranças dos bairros de classe média ali atuantes, mas não demonstrou conhecimento ou proximidade semelhante em relação aos indivíduos e entidades do "OP" (geralmente de origem popular). Podeser arguir, desse modo, que os membros das associações de bairro de classe média são mais visíveis ao entrevistado do que os participantes oriundos das classes populares que atuam no referido fórum.

\section{O caso da Associação de Moradores 2 (AM_2)}

Com base nas informações obtidas, a fundação da AM_2 aconteceu em meados dos anos 2000. O movimento associativo do bairro começou, segundo as informações apuradas no trabalho de campo, em torno da ação dos moradores de uma das ruas do bairro, que se mobilizaram pela preservação da principal característica da referida via: a arborização. A fim de ampliar o movimento dos moradores, foi criada, posteriormente, a associação de moradores do bairro. Esta passou, então, a atuar de forma mais ampla, não ficando mais restrita a um pequeno grupo de residentes de uma só rua. Atualmente, as principais questões trabalhadas pela entidade pesquisada são as seguintes: segurança pública, limpeza urbana, arborização de ruas, revitalização de praças, trânsito, comércio, cuidado com calçadas, mendigos e projetos culturais e artísticos.

O sociograma abaixo retrata a rede egocentrada de um dos indivíduos mais atuantes na AM_2: 


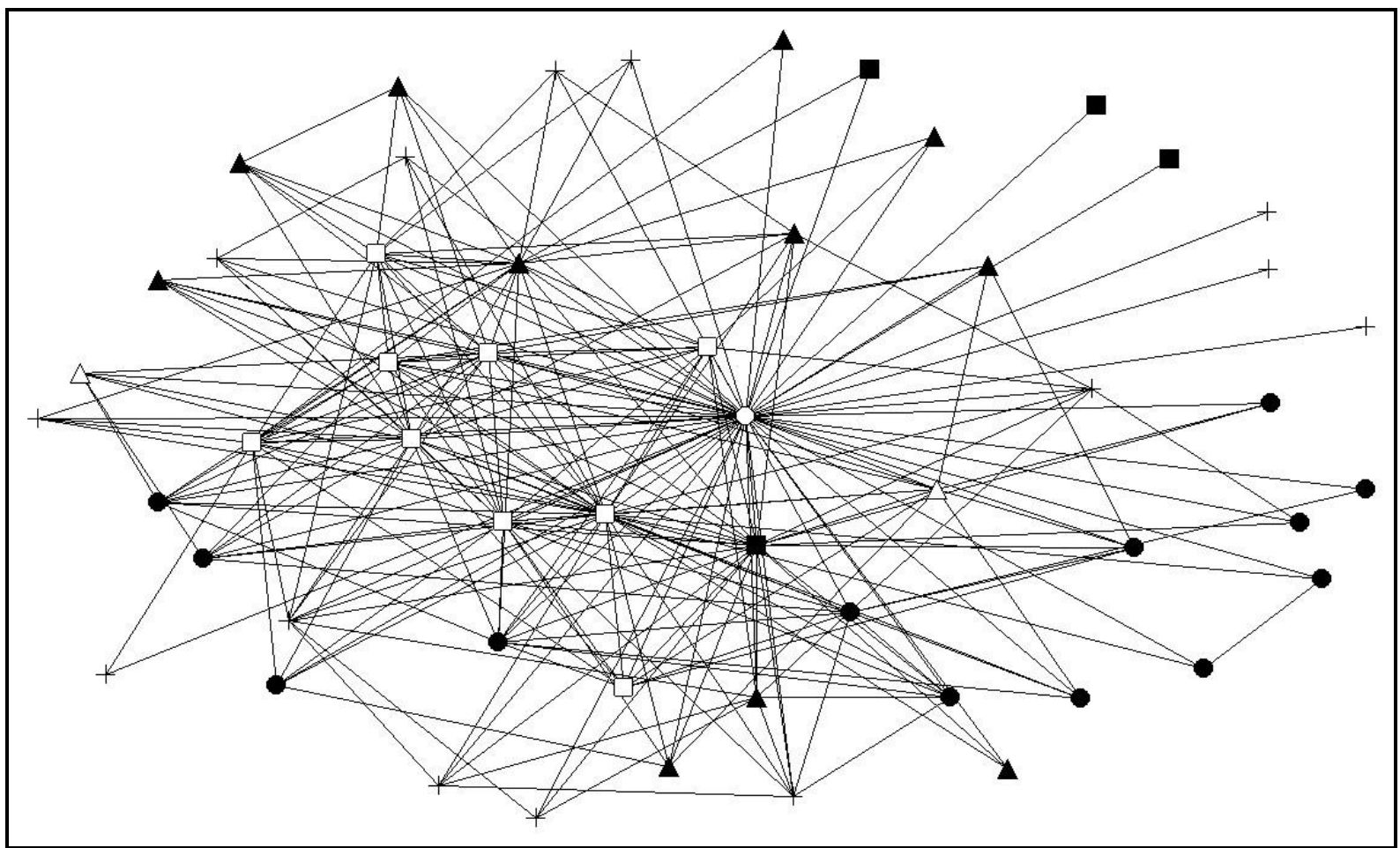

Sociograma 2. Rede egocentrada_002. Fonte: elaboração dos autores a partir do gerador de nomes.

O indivíduo pesquisado tomado aqui como exemplo apresenta as seguintes características: homem, 56 anos, graduado em educação física e com envolvimento mais ativo na associação desde 2009. Além disso, atua profissionalmente como professor de educação física em sua própria academia de ginástica e musculação, a qual se localiza no próprio bairro.

Em termos da caracterização dos 53 alters que compõem a rede egocentrada_002, observa-se que são dezessete mulheres e 36 homens. A grande maioria dos alters - 35 indivíduos - possui ensino superior completo, segundo os dados fornecidos pelo entrevistado ${ }^{10}$. No que tange à inserção profissional dos seus contatos, as informações são as que seguem: dezesseis profissionais liberais com profissões diversas (arquitetos, publicitários, jornalistas, advogados, historiador, engenheiro, assessor); oito servidores públicos (funcionários públicos, professores e policiais); nove indivíduos envolvidos com atividades políticas (vereadores, secretários, deputado, assessor, prefeito); e onze indivíduos com profissões diversas (bancários, diretores de instituições, comerciantes, padre) ${ }^{11}$.

\footnotetext{
${ }^{10} \mathrm{Em}$ outros dez casos, o entrevistado não tinha certeza de que os seus contatos tinham, realmente, 0 ensino superior. Em outros seis, ele não soube informar a escolaridade dos seus alters. E, em dois, informou a escolaridade como sendo de ensino médio.

${ }^{11}$ Em três casos o entrevistado não forneceu a profissão; e, em seis casos, informou somente como aposentado.
} 
REDES- Revista hispana para el análisis de redes sociales

Vol.22,\#4, Junio 2012

http://revista-redes.rediris.es

Já com relação ao bairro de residência dos seus alters, o entrevistado forneceu informações para 30 deles $^{12}$. A tabela 2, a seguir, informa o bairro, o número de residentes em cada bairro, o rendimento médio em salários mínimos dos responsáveis por domicílio e o número médio de anos de estudo dos responsáveis por domicílio. Observa-se, antes de qualquer coisa, que a grande maioria dos seus contatos reside em bairros com indicadores sociais e econômicos bastantes elevados, entre os mais altos da cidade de Porto Alegre, e, em grande medida, semelhantes ao do bairro onde o indivíduo pesquisado mora.

\begin{tabular}{|c|c|c|c|}
\hline Bairro & $\begin{array}{l}\text { Número de } \\
\text { alters } \\
\text { residentes }\end{array}$ & $\begin{array}{l}\text { Rendimento médio } \\
\text { em salários mínimos } \\
\text { dos responsáveis por } \\
\text { domicílio - Bairro* }\end{array}$ & $\begin{array}{l}\text { Número médio de } \\
\text { anos de estudo dos } \\
\text { responsáveis por } \\
\text { domicílio - Bairro* }\end{array}$ \\
\hline Independência & 19 & 20,7 & 13,04 \\
\hline Bom Fim & 3 & 15,25 & 12,67 \\
\hline Moinhos de Vento & 2 & 29,7 & 13,18 \\
\hline Partenon & 2 & 8,1 & 8,90 \\
\hline Auxiliadora & 1 & 19,9 & 12,75 \\
\hline Ipanema & 1 & 15,3 & 9,81 \\
\hline Rio Branco & 1 & 21,2 & 12,83 \\
\hline Floresta & 1 & 12,6 & 10,97 \\
\hline \multicolumn{2}{|c|}{ Porto Alegre } & 9,9 & 9,07 \\
\hline
\end{tabular}

Tabela 2. Perfil sócio-geográfico da rede egoncentrada_002. Fonte: elaboração dos autores a partir do gerador de nomes. *Fonte: Fonte: IBGE - Censo Demográfico - 2000.

Com relação ao padrão e à dinâmica relacional da rede egocentrada_002, percebese a presença de seis grupos de contatos com diferentes perfis de conexão com ego. O primeiro deles diz respeito a indivíduos que integram a atual diretoria da AM_2 e que participam das suas reuniões quinzenais (com exceção de um nó que não participa desses encontros). Essas conexões estão apontadas por quadrados brancos e estão fortemente conectadas entre si.

Um segundo grupo é constituído por dois indivíduos - marcados por triângulos brancos -, os quais têm significativa presença em diversos espaços associativos e participativos da cidade de Porto Alegre, tais como: a Região de Planejamento I, o

\footnotetext{
12 Para quatorze nós o entrevistado forneceu apenas o endereço profissional e para nove contatos ele não soube informar nenhum endereço.
} 
REDES- Revista hispana para el análisis de redes sociales

Vol.22,\#4, Junio 2012

http://revista-redes.rediris.es

Conselho Municipal de Desenvolvimento Urbano e Ambiental (CMDUA), o Fórum de Entidades de Revisão do Plano Diretor, a Associação Gaúcha de Proteção ao Ambiente Natural (AGAPAN), o Movimento em Defesa da Orla do Guaíba e o Comitê em Defesa da Orla do Guaíba.

Há um terceiro conjunto de alters (assinalados por quadrados pretos) que representam as conexões jornalísticas de ego. São pessoas ligadas a jornais que circulam na cidade de Porto Alegre, destacando-se o Jornal Zero Hora e o Jornal Floresta. Este último traz em seu encarte um informe produzido pela AM_2 sobre as suas ações e atividades mais importantes. Chama atenção a alta conectividade de um destes nós na rede egocentrada_002.

O quarto grupo de conexões de ego e que apresenta grande relevância em termos de possibilidade de acesso a recursos, é aquele constituído por indivíduos situados em posição de autoridade, ocupando as mais diversas funções públicas. Esses nós estão marcados por círculos pretos. Entre tais contatos, há a presença do prefeito de Porto Alegre, de cinco vereadores e de um deputado estadual.

O quinto grupo de contatos do entrevistado diz respeito àquelas pessoas que são membros da AM_2, mas que residem ou não no bairro, uma vez que não há a restrição de morar no bairro para ser membro da entidade. Esses nós estão apontados por triângulos pretos. Vale ressaltar a significativa presença de indivíduos que apenas trabalham no bairro ou nos seus arredores e que são procurados por ego para integrarem a AM_2.

Por fim, há um sexto grupo de relações de ego que é constituído por não sócios da entidade, os quais podem ou não residir no bairro. Esses nós estão assinalados por um sinal de mais. São indivíduos, em geral, ligados a instituições situadas no bairro, tais como: o Banco do Brasil, o Colégio Rosário, o Museu de Medicina e a Igreja da Conceição.

Estes dados permitem identificar claramente o padrão homofílico da rede de ego_002 e que tende a se reproduzir na associação na qual ele atua. Tal rede, de um lado, o conecta aos seus "iguais" e, de outro, na medida em que estes "iguais" são ocupantes de posições hierarquicamente superiores (profissionais liberais, religiosos, políticos, jornalistas etc.), oportuniza o acesso a recursos detidos por seus contatos. Assim como no caso de ego_001, apesar de prováveis contatos de ego_002 com indivíduos e entidades em posições socialmente inferiores em função das suas atividades associativas, tais interações não se conformam como laços 
REDES- Revista hispana para el análisis de redes sociales

Vol.22,\#4, Junio 2012

http://revista-redes.rediris.es

significativos e são invisibilizadas na rede social construída a partir das entrevistas. ${ }^{13}$

E, por fim, como opera a segunda dimensão do mecanismo de invisibilização no cotidiano de ego_002? Para responder a tal questionamento, serão explorados, a seguir, os seis principais deslocamentos urbanos feitos por este entrevistado. São três caminhos dentro do seu bairro de residência e outros três itinerários na escala da cidade.

Destes seis percursos, cinco deles têm como ponto de partida o local de trabalho do entrevistado. Isso porque, no momento da entrevista, o próprio indivíduo pesquisado preferiu assinalar como ponto de partida dos seus trajetos a sua academia de musculação e ginástica. Os percursos dentro do bairro são realizados a pé. Já os deslocamentos pela cidade são realizados, em geral, a pé, de ônibus e, às vezes, de automóvel.

O primeiro trajeto explorado tem como ponto de origem a casa do entrevistado, localizada na Rua Santo Antônio. O destino é o seu local de trabalho, situado na Avenida Independência. Um segundo deslocamento acontece ao longo da Avenida Independência, tendo como origem o local de trabalho do entrevistado. Este trajeto tem dois destinos: a região central da cidade e a Praça Julio de Castilho, situada na outra ponta deste deslocamento. O entrevistado ressaltou, ao ser perguntado sobre suas impressões sobre tal trajeto, os problemas causados pelos mendigos e moradores de rua. O terceiro deslocamento pelo bairro se dá até a Rua Gonçalo de Carvalho. Trajeto este que é realizado por vários caminhos: um pela Rua Santo Antônio, outro pela Rua Ramiro Barcellos, outro pela Rua Tiradentes e outro pela Rua Pinheiro Machado. Quando questionado acerca de tal percurso, o entrevistado informou que a Rua Gonçalo de Carvalho se tornou um dos atrativos do bairro, desempenhando um papel de publicidade e de divulgação do bairro e, sobretudo, das ações da associação de moradores da qual ele participa.

Com relação aos deslocamentos pela cidade, o primeiro deles vai do local de trabalho até a Usina do Gasômetro. Esse trajeto é realizado, tanto pela Rua dos Andradas, quanto pela Rua Duque de Caxias. Nesse deslocamento o entrevistado passa por diversos locais vinculados a atividades artístico-culturais (museus e

\footnotetext{
13 Por exemplo, em 2011, ego_002 manteve contatos em diversas oportunidades com agentes sociais residentes no bairro Floresta a partir de atividades da Associação de Moradores. Porém, esses contatos não se transformaram em conexões sociais mais efetivas e significativas para o entrevistado. Além disso, inúmeras vezes ao longo do trabalho de campo, ele delimitou claras diferenças entre os bairros Floresta e Independência. Pode-se inferir que, em certa medida, esses "novos" agentes sociais conhecidos por ego_002 permaneceram "invisíveis" para ele.
} 
REDES- Revista hispana para el análisis de redes sociales

Vol.22,\#4, Junio 2012

http://revista-redes.rediris.es

cinemas, sobretudo), tais como: a Casa de Cultura Mario Quintana, o Museu de Artes do Rio Grande do Sul, o Santander Cultural, o Solar dos Câmara, o Teatro São Pedro e a Usina do Gasômetro. É um caminho pelo Centro Histórico, conforme enfatizou o entrevistado.

O seu segundo descolamento pela cidade tem como destino o bairro Cidade Baixa, realizado tanto pela Rua Venâncio Aires quanto pelo Parque da Redenção. Um dos motivos deste deslocamento é ir ao cinema que se localiza no Shopping Olaria.

Por fim, o terceiro, mais recente e mais longo deslocamento tem como destino a Escola Superior de Educação Física da Universidade Federal do Rio Grande do Sul, situada na Rua Felizardo, na divisa dos bairros Petrópolis e Jardim Botânico.

A descrição dos deslocamentos urbanos realizados por ego_002 permite identificar um padrão de trânsito relativamente similar ao observado no caso de ego_001: a tendência à circulação por espaços urbanos marcados pela presença de indivíduos que compartilham a posição social do entrevistado. Destaca-se ainda, no caso de ego_002, que quando os indivíduos em posições inferiorizadas são percebidos nos trajetos, estes tendem a aparecer como "problemas" (mendigos, moradores de rua) a serem resolvidos.

\section{Considerações Finais}

A análise das redes e dos percursos urbanos dos dois casos apresentados neste artigo permite sustentar empiricamente a presença e a importância do mecanismo da invisibilização na (re)produção das distâncias sociais (e, assim, da homofilia) nas redes associativas. De um lado, a invisibilização se expressa na tendência de que indivíduos em posições subalternizadas estejam ausentes dos espaços e das relações que estruturam o cotidiano dos indivíduos pesquisados. Tal ausência diminui (e, no limite, impede) a possibilidade de que relações significativas e duradouras se estabeleçam entre desiguais.

De outro lado, mesmo quando aquela tendência é rompida e os entrevistados interagem com indivíduos e organizações em posições sociais inferiorizadas, observa-se que tal interação tende a não produzir vínculos relevantes. Nos dois casos explorados, tais indivíduos e organizações se colocam mais como parte do "contexto" no qual atuam e menos como sujeitos com os quais os entrevistados estabelecem relações que eles identificam como significativas.

Os resultados da pesquisa parecem sustentar o argumento de que, em contextos de desigualdades extremas como o brasileiro, a invisibilização tende a assumir uma tal centralidade na (re)produção das fronteiras sociais e simbólicas que inclusive 
REDES- Revista hispana para el análisis de redes sociales

Vol.22,\#4, Junio 2012

http://revista-redes.rediris.es

limita a presença/atuação de outros mecanismos de classificação e hierarquização social - tais como a estigmatização ou a distinção, enfocados por Elias e Scotson (2000) e Bourdieu (2007). Nos casos analisados, é claro, é possível identificar atos de estigmatização e distinção (como nas referências aos moradores de ruas e mendigos como "problemas urbanos"). No entanto, em geral, observa-se que os subalternos simplesmente "não existem" nos espaços e redes que conformam o cotidiano dos entrevistados e, assim, não se constituem em objeto de suas considerações e ações.

Este talvez seja um dos principais desafios metodológicos na identificação e análise empírica do mecanismo da invisibilização: como apreender uma ausência? Diferentemente dos casos de estigmatização e distinção, nos quais o "inferior" está presente como desvalorizado/desqualificado, no caso da invisibilização o "inferior" está ausente. Assim, os indicadores da invisibilização e da sua operação são exatamente a falta de referência e a não identificação. É no não dito e no silêncio que se expressa de forma "gritante" a invisibilidade dos subalternos.

A apreensão e a explicação da presença e reprodução das desigualdades sociais em redes associativas marcadas pela segmentação e homofilia constitui um desafio teórico e metodológico para o campo de estudos da sociedade civil, na medida em que desafia as concepções dominantes neste campo que enfatizam as características e os efeitos democratizantes e igualitários do associativismo. Ao contrário, os resultados da presente pesquisa suportam as hipóteses de Kerstenetzky que afirma:

"quando as desigualdades socioeconômicas são 'duráveis' e elevadas é bem plausível que se repliquem no interior da vida associativa, bem como entre grupos organizados e não organizados, enfraquecendo a habilidade da inclusão política da participação associativa. Além disso, não parece claro que a intensificação da vida associativa conduza a uma redução das desigualdades sobre as quais se plasma" (Kerstenetzky, 2003, p.132).

Identificar os mecanismos através dos quais esta replicação das desigualdades na vida associativa ocorre constitui uma importante agenda de pesquisa para os estudiosos da sociedade civil. Entre estes mecanismos, conforme analisado neste artigo, sem dúvida a invisibilização ocupa uma posição de destaque. 
REDES- Revista hispana para el análisis de redes sociales

Vol.22,\#4, Junio 2012

http://revista-redes.rediris.es

\section{Referências bibliográficas}

Banton, Michael (1960). Social distance: a new appreciation. pp.169-183.

Bogardus, Emory S (1925a). Social distance and its origins. Journal of Applied Sociology, v.9, pp.216-226.

Bogardus, Emory S. (1925b). Measuring Social Distances. Journal of Applied Sociology, v.9, pp.299-308.

Boissevain, Jeremy (1974). Networks: interaction and structure. In: BOISSEVAIN, Jeremy. Friends of friends: networks, manipulators and coalitions. New York: St. Martin's Press.

Boissevain, Jeremy (1979). Network analysis: a reappraisal. Current Anthropology, v.20, n. 2, pp.392-394.

Bottero, Wendy (2005). Stratification: social division and inequality. London: Routledge.

Bourdieu, Pierre (1996). Espaço social e espaço simbólico. In: BOURDIEU, Pierre. Razões práticas: sobre a teoria da ação. Campinas: Papirus.

Bourdieu, Pierre (2005). O poder simbólico. 8.ed. Rio de Janeiro: Bertrand Brasil.

Bourdieu, Pierre (2007). A distinção: crítica social do julgamento. São Paulo: EDUSP, Porto Alegre: Zouk.

Bidart, Claire; Charbonneau, Johanne (2007). The contextual name generator: a good tool for the study of sociability and socialization. Communication presented at the XXVII Sunbelt, Corfou, 1-6 May.

Burt, Ronald S. (2009). Appendix A. Measuring the network. In: Burt, Ronald S. Neighbor networks: competitive advantage local and personal. Oxford: Oxford University Press.

Elias, Norbert; Scotson, John L. (2000). Os estabelecidos e os outsiders. Rio de Janeiro: Jorge Zahar Editor.

Emirbayer, Mustafa (1997). Manifesto for a relational sociology. The American Journal of Sociology, v.103, n.2, pp.281-282.

Emirbayer, Mustafa; Goodwin, Jeff (1994). Network analysis, culture, and the problem of agency. The American Journal of Sociology, v.99, n.6, pp. 1411-1454.

Hedström, Peter; Swedberg, Richard (1996). Social mechanisms. Acta Sociologica, n.3, v.39, pp.281-308. 
REDES- Revista hispana para el análisis de redes sociales

Vol.22,\#4, Junio 2012

http://revista-redes.rediris.es

Kerstenetzky, Celia Lessa (2003). Sobre associativismo, desigualdades e democracia. Revista Brasileira de Ciências Sociais, vol.18, n.53, pp. 131-142.

Lago, Luciana Corrêa do; Ribeiro, Luiz César de Queiroz (2001). A divisão favelabairro no espaço social do Rio de Janeiro. Cadernos da Metrópole, n.5, pp.30-46.

Labache, Lucette; Saint-Martin, Monique de. Fronteiras, trajetórias e experiências de rupturas. Educação \& Sociedade, v. 29, n.103, pp.333-354, maio-ago. 2008.

Lamont, Michèle; Molnár, Virág (2002). The study o boundaries in the social sciences. Annual Review of Sociology, v.28, pp.167-195.

Lynch, Kevin (2006). A imagem da cidade. Martins Fontes: São Paulo.

Mahoney, James (2001). Beyond correlational analysis: recent innovations in theory and method. Sociological Forum, n.3, v.16, pp.575-593.

Mahoney, James (2003). Tentative answers to questions about causal mechanisms. Paper presented at the annual meetings of the American Political Science Association, Philadelphia, August 28, pp.1-17. Disponível em: <http://www.allacademic.com//meta/p_mla_apa_research_citation/0/6/2/7/6/page s62766/p62766-18. php>. Acesso em: 16 de nov. de 2010.

Marin, Alexandra; Hampton, Keith N. (2007). Simplifying the personal network name generator: alternatives to traditional multiple and single name generators. Field Methods, v.19, n.2, pp-163-193.

Marques, Eduardo (1999). Redes sociais e instituições na construção do Estado e da sua permeabilidade. Revista Brasileira de Ciências Sociais, São Paulo, v.14, n.41, p.45-67.

Marques, Eduardo (2006a). Redes sociais e poder no Estado brasileiro: aprendizados a partir das políticas urbanas. Revista Brasileira de Ciências Sociais, São Paulo, v.21, n.60, p.15-41.

Marques, Eduardo et. al. Redes pessoais e pobreza em São Paulo. (2006b). Disponível em: <http://www.cebrap.org.br/v1/upload/biblioteca_virtual/MARQUES et al_Redes Pessoais e Pobreza.pdf>. Acesso em: 25 de out. de 2010.

Marques, Eduardo (2009). As redes sociais importam para a pobreza urbana? Dados, Rio de Janeiro, v.52, n.2, pp.471-505.

Marques, Eduardo (2010). Redes sociais, segregação e pobreza. São Paulo, Editora UNESP; Centro de Estudos da Metrópole. 
REDES- Revista hispana para el análisis de redes sociales

Vol.22,\#4, Junio 2012

http://revista-redes.rediris.es

Mayntz, Renate (2004). Mechanisms in the analysis of social macro-phenomena. Philosophy of the Social Sciences, v.34, n.2, pp.237-259.

McPherson, Miller; Smith-Lovin, Lynn; Cook, James M. (2001). Birds of a feather: homophily in social networks. Annual Review of Sociology, 27.

Mische, Ann (2008). Partisan Publics: communication and contention across Brazilian youth activist networks. Princeton University Press.

Pachucki, Mark A.; Pendergrass, Sabrina; Lamont, Michèle (2007). Boundary processes: recent theoretical developments and new contributions. Poetics, v.35, n.6. pp.331-351.

Park, Robert Ezra (1924). The concept of social distance as applied to the study of racial attitudes and racial relations. Journal of Applied Sociology, v.8, pp.339-344.

Prefeitura/Secretaria de Coordenação Política e Governança Local et. al. (2008). Atlas do desenvolvimento humano da Região Metropolitana de Porto Alegre. Porto Alegre. CD-ROM.

Saint-Martin, Monique de; Rocha, Daniella de Castro; Heredia, Mariana (2008). Trocas intergeracionais e construção de fronteiras sociais na França, Tempo Social, v.20, n.1, pp.135-162.

Silva, Marcelo Kunrath; zanata JR. Rui (2010). Desigualdade e associativismo: proximidade espacial e distância social na conformação da sociedade civil. Revista Brasileira de Estudos Urbanos e Regionais, v.10, n.2, Nov.

Sorokin, Pitirim (1973). A. Espaço social e posição social. In: Cardoso, Fernando Henrique; Ianni, Octávio. Homem e sociedade: leituras básicas de sociologia geral. São Paulo: Companhia Editora Nacional, pp.223-230.

Tilly, Charles (2004). Social boundary mechanisms. Philosophy of the Social Sciences, v.34, n.2, pp.211-236.

Tilly, Charles (2005). Ties that bind... and bound. In: Tilly, Charles. Identities, boundaries, and social ties. Paradigm Publishers, Boulder/London. pp.3-10.

Vehovar, Vasja et. al. (2008). Measuring ego-centered social networks on the web: questionnaire design issues. Social Networks, v.30, pp.213-222.

Zanata JR. Rui. (2009). Desigualdade e associativismo: um estudo comparativo sobre capital social e participação política com duas associações de moradores de Porto Alegre. 67 f. Monografia (Trabalho de Conclusão de Curso de Sociologia) - 
REDES- Revista hispana para el análisis de redes sociales

Vol.22,\#4, Junio 2012

http://revista-redes.rediris.es

Departamento de Sociologia, Universidade Federal do Rio Grande do Sul, Porto Alegre, 2009.

Wellman, Barry (1983). Network analysis: some basic principles. Sociological Theory, v.1, pp.155-200. 